12. Shats'kyy, V. V., \& Povolots'kyy, A. A. (2015). Osnovni vymohy do protsesu ta biotekhnichnoyi systemy kompostuvannya orhanichnoyi syrovyny. Visnyk Kharkivs'koho natsional'noho tekhnichnoho universytetu sil's'koho hospodarstva imeni Petra Vasylenka,157, 140-146. http://nbuv.gov.ua/UJRN/Vkhdtusg_2015_157_26.

13. Fierer N, Jackson RB. The diversity and biogeography of soil bacterial communities. PNAS. 2006 Jan 17; 103(3): 626-31 https://www.ncbi.nlm.nih.gov/pubmed/16407148

Отримано в редакцію 18.04.2018

Прийнято до друку 30.06.2018
Received 18.04.2018

Approved 30.06.2018

УДК 62229.316.002.51/52:665.3

DOI: http://dx.doi.org/10.15673/swonaft.v82i1.1014

\title{
ФОРМУВАННЯ ТЕХНОЛОГІЇ ОЧИСТКИ РОСЛИННОЇ ОЛІї В УМОВАХ МІНІ-ЦЕХІВ
}

\author{
Осадчук П. І. кандидат технічних наук, доцент \\ Дударєв I. I. кандидат технічних наук, доцент \\ Одеський державний аграрний університет, м. Одеса
}

\begin{abstract}
Анотація: Створено комплекс технічних засобів, щчо включає обладнання $і$ блоки пресування насіння, адсорбентної рафінації, гідратаиії $і$ коагуляиії, центрифугування $і$ дезодорації, очищення $і$ мікрофільтрачії олії. Конструкиї технічних засобів дозволяють компонувати окремі складові частини поблочно (модульно), враховуючи умови їх розміщення у мало контурних цехах. У технологічному процесі, за необхідності використовується ультразвуковий кавітатор для зниження кислотності олії. Сформований за ичим принципом комплекс забезпечує одержання екологічно чистої рослинної олії за безвідхідною технологією, щзо актуальна для фермерських господарств. Олія такої якості відноситься до категорії кашерних продуктів.
\end{abstract}

Ключові слова: агровиробництво, олія рослинна, технологія, обладнання, показники якості.

\section{FORMATION OF PLANE OLIVE CLEANING TECHNOLOGIES IN MINI-SHOPS CONDITIONS}

\author{
Osadchuk P.I., PhD, associate professor \\ Dudarev I.I., PhD, associate professor \\ Odessa state agricultural university, Odessa, Ukraine
}

\begin{abstract}
To obtain high-quality edible oils, these should be as much as possible cleaned from concomitant substances, mechanical impurities, phosphatides, waxes, soap and hydrophobic fractions. This process can be realized on the basis of physical methods developed by us with the help of special centrifugal devices, ceramic microfilters, hydration means for purifying phosphatidic concentrate with subsequent belting filtration of monodibasic unsaturated acids A complex of technical means was developed, including equipment and blocks for pressing the seed, adsorbent refinement, hydration and coagulation, centrifugation and deodorization, cleaning and microfiltration of oils. Structures of technical means allow to compose separate components of a unit (modular), taking into account the conditions of their placement in small contour workshops. In the technological process, if necessary, an ultrasonic cavitator is used to reduce the acidity of the oil. The complex formed on this principle ensures the production of ecologically pure vegetable oil in the non-waste technology and in the conditions of the farms. Oil of this quality belongs to the category of casserole products.The technological process involves pressing the seeds, then feeding to a centrifuge for purification from mechanical impurities, for removing water and lightly flowing fractions into a vacuum chamber and microfiltration and lighting in the supercleaner unit, an ultrasonic cavitator is used to reduce the acidity of the oil. The vegetable oil retains its organoleptic qualities and the nutritional value of the product. Such an effect is achieved by the use of only the production of oils, physical and mechanical processes, without chemical treatment. The technology is implemented by a compact small-scale technical complex, executed in a modular-block type, which is easy to control.
\end{abstract}

Key words: agricultural production, vegetable oil, technology, equipment, quality indices.

Вступ. На сьогодні в міні-цехах агровиробництва і фермерських господарств широко розповсюджена спрощена технологія отримання соняшникової олії, що базується на простому і не дорогому обладнанні. Однак, ця технологія не включає в себе наступну очистку олії, яка відповідала би діючим стандартам якості продукту щодо вмісту механічних домішок та канцерогенних речовин.

Актуальність. Левова частка всіх показників якості олії припадає на процес очищення. Отож чим краще очищена олія - тим вона якісніша, в певній мірі. Отриманні рослинні олії містять різні механічні домішки, супутні речовини, білкові, слизисті, ароматичні речовини, пігменти, можуть містити продукти розпаду жирів (вільні жирні кислоти і продукти їх окислення) та інші. Багато з них забезпечують специ-

Наукові праці, Том 82, випуск 1 Scientific Works, Volume 82, Issue 1 
фічний запах, смак і колір олій. Використовувані для харчових цілей рослинні олії мають бути нейтральними. Тому актуальним $\epsilon$ визначення оптимального режиму проведення технологічного процесу очистки соняшникової олії з використанням фізичних полів. 3 метою отримання скорочення часу очистки та зменшення енерговитрат при отримані продукції вищої якості.

Аналіз літературних джерел. У процесі вилучення олії утворюються умови, які сприяють переходу у нього супутніх речовин, визначаючих у подальшому вибір режимів, апаратури та схеми очистки олії в залежності від подальшого його використання. К таким речовинам відносяться фосфатиди, віск, вільні жирні кислоти, пігменти та інш. Ці речовини присутні в олії у невеликій кількості, але деякі 3 них істотно впливають на іï якість та технологічні властивості [7,8]. Крім того аналіз інтернет ресурсу та літературних джерел, дозволив дійти висновку, що дана проблема досить актуальна, однак наукові пошуки відносно використання фізичних полів для очистки олій рослинного походження практично відсутні.

Мета досліджень. Для отримання високоякісних харчових олій їх необхідно максимально очистити від супутніх речовин, тобто механічних домішок, фосфатидів, восків, мильних речовин та гідрофобних фракцій. Цей процес можливо реалізувати за розробленою нами технологією на базі фізичних методів із допомогою спеціальних відцентрованих апаратів, керамічних мікрофільтрів, гідраційного способу очистки фосфатидного концентрату із наступною бельтинг-фільтрацією одно-двохосновних ненасичених кислот [1-6].

Результати експериментальних досліджень. Технологічна модель доочистки соняшникової олії фізичними методами включає в себе використання ультразвукового поля з метою інтенсифікації процесу очистки. Відомо, що при збільшенні частот довжина хвилі ультразвуку наближається до величини, порівнянної з міжмолекулярними відстанями, що впливає на структуру та енергетику середовища, а отже змінюе іï фізико-механічні властивості. Ці зміни поширюються в просторі нерівномірно, тому що інтенсивність ультразвукових хвиль зменшується внаслідок поглинання в середовищі. Так виникає проблема неоднорідності оброблюваного ультразвуком матеріалу, що вирішується оптимальним розташуванням джерела ультразвуку відповідно до форми та розмірів робочого простору, а також вибором оптимального часу дії ультразвуку. Оптимізацію вібраційної обробки за допомогою ультразвуку можна науково обгрунтувати, якщо знати закон коливання в кожній крапці робочого простору. Такі завдання вирішуються методами математичної фізики на основі хвильового рівняння

$$
\Delta^{2} \Phi-\frac{1}{c^{2}} \frac{\partial^{2} \Phi}{\partial t^{2}}=0
$$

де с - швидкість розповсюдження хвилі

Для поперечних коливань завдання приводиться до інтегрування рівняння

$$
\frac{\partial^{2} U}{\partial t^{2}}=a^{2} \frac{\partial^{2} U}{\partial x^{2}}
$$

Для поздовжніх коливань завдання приводиться до рішення рівняння (2) при умовах:

$$
\begin{gathered}
U(0, t)=0, \quad \frac{\partial U(l, t)}{\partial x}=\frac{A}{E} \sin \omega t ; \\
U(x, 0)=0, \quad \frac{\partial U(x, 0)}{\partial t}=0
\end{gathered}
$$

Отже, віссесимметрична задача поширення ультразвуку представляється функцією $\phi(r, z, t)=G(r) H(z) T(t)$, яка визначається рішенням рівнянь:

$$
\begin{gathered}
\phi(r, z, t)=\sum_{n=1}^{\infty} b_{n} I_{0}\left(K_{n} r\right)\left(\sin \sqrt{\lambda_{n}^{2}+K_{n}^{2} z}\right) \sin K_{n} c t, \\
b_{n}=(-1)^{n-1} \frac{2 \alpha \omega}{E l \gamma_{n}}, \\
\lambda_{n}=\sqrt{\frac{1}{l} \arcsin \frac{\sin \gamma_{n} l}{\omega^{2}-\alpha^{2} \gamma_{n}^{2}}} .
\end{gathered}
$$

Рішення (4) містить модуль пружності вібратора та швидкість поширення хвиль пружності в його матеріалі, а також швидкість поширення ультразвуку в рослинній олії. Геометричні параметри $h, l$ і $\boldsymbol{R}$ ємності з рослинною олією варто вибирати залежно від критерію оптимальності відповідно до вимоги технології обробки ультразвуком, у який оптимальний час можна знаходити, використовуючи функцію $\phi(r, z, t)$. Існування оптимального часу обробки рослинного масла можна пояснити тим, що дія ультразвуку, викликає як коагуляцію дрібних твердих часток так і здрібнювання твердих часток. Завдяки тому, що здрібнювання та коагуляція протилежні за результатами їхньої дії, обробка ультразвуком зважених у соняшникової олії часток має оптимальний час дії.

У результаті проведення експериментальних досліджень впливу ультразвуку на процес очищення олії отримали слідуючи результати:

Наукові праці, Том 82, випуск 1 Scientific Works, Volume 82, Issue 1 
Проаналізувавши експериментальні дані, можна зробити висновки, що досягнення максимального ефекту по видаленню зважених речовин відбувається при наступних технологічних параметрах: потужність ультразвукових коливань 1,3 кВт, частота ультразвукових коливань 120 кГц, час обробки 450 секунд, температура олії $50{ }^{\circ} \mathrm{C}$. Погрішність теоретичного та практичного експерименту не перебільшує 10 відсотків В порівнянні зі звичайною фільтрацією, при обробці ультразвуковим полем видалення домішок збільшилось на $12 \%$.

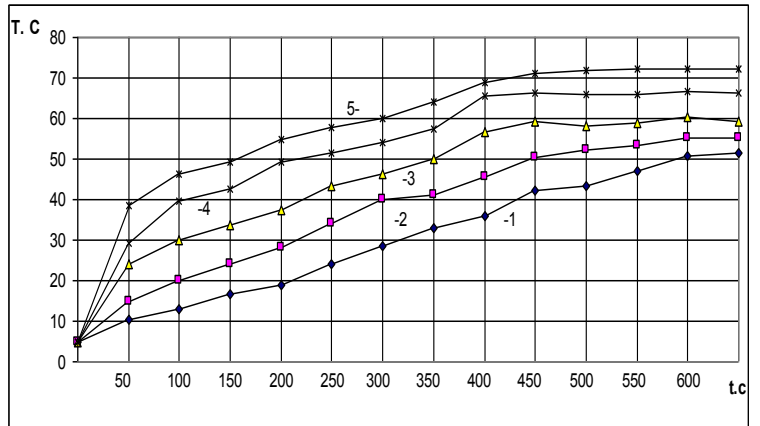

Рис.1 Визначення часу нагріву олії при зміні частоти ультразвукових коливань опромінювача: 1 - 24 кГц, 2 - 50 кГц, 3 - 75 кГц, 4 - 115 кГц, 5 - 130 кГц.

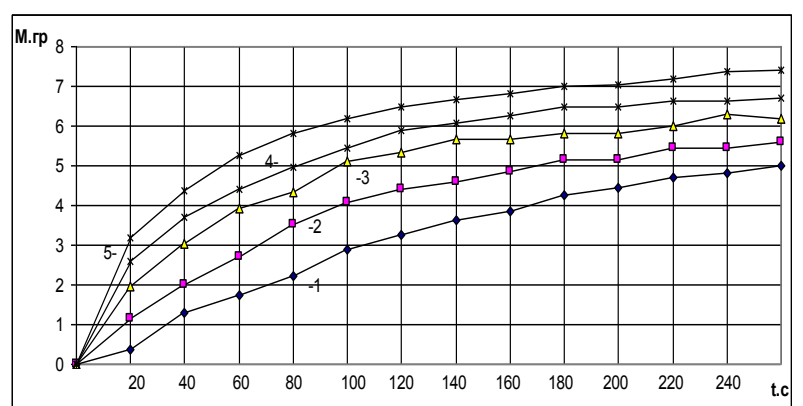

Рис.2 Визначення кількості осаду при потужності опромінювача 1,3 кВт, та різної температурі олії: $1-20{ }^{\circ} \mathrm{C}, 2-30{ }^{\circ} \mathrm{C}, 3-40{ }^{\circ} \mathrm{C}, 4-$ $50{ }^{0} \mathrm{C}, 5-60{ }^{\circ} \mathrm{C}$.

Для реалізації технології одержання рослинної олії пропонується комплекс технічних засобів, який містить:

1. Блок пресування (серійного виготовлення).

2. Блок коагуляції і гідратації.

3. Блок центрифугування.

4. Блок вакуумного сушіння.

5. Блок суперочищення (мікрофільтраціі).

6. Блок пресування (серійного виготовлення).

7. Блок коагуляції і гідратації.

8. Блок центрифугування.

9. Блок вакуумного сушіння.

10. Блок суперочищення (мікрофільтрації).

Конструкції технічних засобів дозволяють компонувати окремі складові частини поблочно (модульно), враховуючи умови їх розміщення у малоконтурних цехах. При наявності обладнання для пресування (п.1), необхідно виготовити і впровадити у виробництво тільки устаткування по п. п. 2-5.

Комплекс технічних засобів забезпечує пресування олійного насіння, очищення від механічних домішок центрифугуванням, видалення води під вакуумом, суперочищення (освітлення), коагуляцію й гідратацію олії. Призначений для одержання екологічно чистої олії з насіння соняшника.

Технологічний процес виконується в такій послідовності. Олійне насіння підлягає пресуванню, потім неочищена олія подається на центрифугу для очищення від механічних домішок. Очищена олія потрапляє до вакуумної камери для видалення води і легкокиплячих фракцій, потім подається в блок суперочищення для мікрофільтрації і освітлення. В технологічному процесі, при необхідності використовується ультразвуковий кавітатор для зниження кислотності олії.

Сформований за цим принципом комплекс забезпечує одержання екологічно чистої рослинної олії по безвідхідній технології і в умовах фермерських господарств.

Технічна характеристика комплексу:

Номінальне виробництво, л/год - 150-450.

1. Залишковий вміст механічних домішок, не більш 0,005 \% масових. Залишковий вміст води в олії - відсутня.

2. Споживча потужність, кВт $-9,5$

3. Сировина - насіння соняшника.

4. Персонал - один оператор.

Ефективність методу одержання освітленої екологічно чистої рослинної олії при повному збереженні органолептичної якості і поживній цінності продукту. Такий ефект досягається застосуванням при виробництві олії тільки фізично-механічних процесів, без хімічної обробки. Технологія реалізується компактним малогабаритним технічним комплексом, виконаним по модульно-блочному типу, яким легко керувати. Він зручний та компактний. 
Сформована за таким принципом технологія і розроблене обладнання впроваджені в ТОВ “Прогрес" (с. Кремидівка, Одеської області). Отримано позитивні результати, 100 г рослинної олії в середньому містить:

жирів - 99,9 г;

холестерину - нуль г;

вітамінів А - 27 мг., Е - 125 мг.;

жирні кислоти - насичені - 11,1 г.;

мононасиченні - 59,3 г.

Калорійність олії 3693 кДж (898 ккал), зберігає смак і аромат свіжевіджатої олії за своєю якістю відноситься до кашерних продуктів.

Показники якості олії приведені у таблиці 1.

Таблиця 1

Показники якості олії

\begin{tabular}{|c|c|c|}
\hline № п/п & Найменування показників & Показники \\
\hline 1 & Сорт & Дезодорована \\
\hline 2 & Масова доля вологи та летючих речовин, \% & 0,1 \\
\hline 3 & Ступінь прозорості, фен. & 25 \\
\hline 4 & Кислотне число, мГКОН $/ \Gamma$ & 0,35 \\
\hline 5 & Перекисне число, мМоль/кг & 5,0 \\
\hline 6 & Кольорове число, мг йоду & 10 \\
\hline
\end{tabular}

Показники якості олії з насіння соняшника відповідають діючому стандарту ДГСТ 1129-93 “Олія соняшника".

Висновки. Сформована прогресивна технологія і створено комплекс технічних засобів для здійснення процесу отримання якісної рослинної олії з насіння соняшника. Ефективність запропонованої технології і технічного комплексу обладнання для іiї реалізації - отримання екологічно чистої олії при повному збереженні органолептичної якості і поживної цінності продукту.

\section{Література.}

1. Топілін Г. Є., Гальцев В. П. Технічний комплекс для виробництва екологічно чистої рослинної олії. //Аграрний вісник Причорномор'я: Зб. Наук. Праць /Одеський ДСГІ. - Одеса: ОДСГІ. - 2000. - №3(11). - с.37-39.

2. Топілін Г. С., Гальцев В. П., Савченко О. Я. Установка модульно - блочного типу очищення рослинної олії. //Аграрний вісник Причорномор'я: Зб. Наук. Праць /Одеський ДСГІ. - Одеса: ОДСГІ. - 2001. - №4(15). - c.46-51.

3. Топілін Г. Є., Осадчук П. І., Гальцев В. П. Ефективний метод отримання “живої” рослинної олії. //Аграрний вісник Причорномор’я: Зб. Наук. Праць /Одеський ДСГІ. - Одеса: ОДСГІ. - 2002. - №19. - с.91-94.

4. Топілін Г. Є., Гальцев В. П., Богаченко С. Д. Гідротація рослинної олії. //Технології 21 века. - Міжнародна наукова конференція, Т. 2, с.90-95, Алушта, 2003.

5. Гальцев В. П. Ефективний метод мікрофільтрації рослинної олії в умовах фермерського господарства. //Аграрний вісник Причорномор’я: Зб. Наук. Праць /Одеський ДАУ. - Одеса: ОДАУ. - 2003. - №22. - с.723-726.

6. Осадчук П.І., Топілін Г. Є., Гальцев В. П. Гідратація рослинної олії, коагуляція фосфатидів і вощини. //Аграрний вісник Причорномор'я, Технічні науки - 2004 - № 24 - С.28 - 32.

7. Технология производства растительных масел. В. М. Копейковский, С. И. Данильчук, Г. И. Гарбузова и др. под ред. В. М. Копейковского. - М.: Легкая и пищевая промышленность, 1982. - 416 с.

8. Жири и масла. Производство, состав и свойства, применение. /Р. О' Брайен: пер. с англ. 2-го изд. В. Д. Широкова, Д. А. Бабейкеной, Н. С. Селивановой, Н. В. Маглы - СПб: Профессия, 2007. - 752 с.

\section{References}

1. Topilin, G. E., Galtsev, V. P. (2000) TehnIchniy kompleks dlya virobnitstva ekologIchno chistoyi roslinnoyi olIYi. Agrarniy vIsnik Prichornomor'ya: Zb. Nauk. Prats.Odeskiy DSGI. Odesa: ODSGI. 3(11). 37-39.

2. TopIlIn, G. E., Galtsev, V. P., Savchenko O. Ya. (2001) Ustanovka modulno - blochnogo tipu ochischennya roslinnoyi oloyi. Agrarniy vIsnik Prichornomor'ya: Zb. Nauk. Prats Odeskiy DSGI. Odesa: ODSGI. 4(15). 46-51.

3. TopIIIn, G. E., Osadchuk, P. I., Galtsev, V. P. (2002) Efektivniy metod otrimannya "zhivoYi" roslinnoYi olIYi. Agrarniy vIsnik Prichornomor'ya: Zb. Nauk. Prats. Odeskiy DSGI. Odesa: ODSGI. 19. 91-94.

4. TopIlIn, G. E., Galtsev, V. P., Bogachenko, S. D. (2003) GIdrotatsIya roslinnoYi olIYi. Tehnologiyi 21 veka. Mizhnarodna naukova konferentsIya, Alushta, 2, 90-95.

5. Galtsev, V. P. (2003) Efektivniy metod mIkroflltratsIYi roslinnoYi olIYi v umovah fermerskogo gospodarstva. Agrarniy vIsnik Prichornomor'ya: Zb. Nauk. Prats. Odeskiy DAU. - Odesa: ODAU. 22. 723-726.

6. Osadchuk, P.I., TopIIIn, G. E., Galtsev, V. P. (2004) GIdratatsIya roslinnoYi olIYi, koagulyatsIya fosfatidIv I voschini. Agrarniy vIsnik prichornomor'ya, TehnIchnI nauki. 24. 28 - 32.

7. Kopeykovskii, V.M., Danilchuk, S.I., Garbuzova, G.I. [Ed. V. M. Kopeikovsky] (1982) Technology of production of vegetable oils., and others. Moscow: Light and Food Industry, 416.

8. Bryan, R.O [Trans. with English. 2nd ed. Shirokova, V.D., Babeykenoy, D.A., Selivanova, N.S., Magly N.V.] (2007) Fat and oil. Production, composition and properties, application. St. Petersburg: Profession,. 752.

Отримано в редакцію 18.04.2018

Прийнято до друку 30.06.2018
Received 18.04.2018

Approved 30.06.2018 